\title{
Desmercantilização do Trabalho da Perspectiva do Movimento Sindical (Brasil, 1950-2000)
}

\author{
Valéria Marques Lobo
}

\section{INTRODUÇÃO}

\begin{abstract}
A história do movimento sindical tem revelado duas disposições desse ator no que se refere à relação entre capital e trabalho. De um lado a tentativa, via ação coletiva, de estabelecer condições favoráveis à venda da força de trabalho, impedindo que seu preço seja determinado pelo intercâmbio entre os capitalistas e os trabalhadores individuais exclusivamente por meio do mercado. De outro, também via ação coletiva, a luta pelo estabelecimento de limites à conversão plena da própria força de trabalho em mercadoria, por sua desmercantilização, através de políticas regulatórias, compensatórias, preventivas e redistributivas ${ }^{1}$. Nesse caso, o que se busca é reduzir o despotismo do capital, seja mitigando o poder de que dispõem os empresários em relação ao uso da força de trabalho, seja retirando da esfera do mercado aspectos diversos da reprodução da força de trabalho, incluindo os que afetam as condições de existência das diversas modalidades de superpopulação relativa que acompanham as diferentes trajetórias de desenvolvimento capitalista.
\end{abstract}

No limite, a utopia do mercado autorregulado corresponde à imagem de uma sociedade capitalista totalmente mercantilizada. Esse momento fugaz e improvável não envolveria qualquer tipo de interferência política no mercado. Por seu turno, a presença de direitos sociais, que

DADOS - Revista de Ciências Sociais, Rio de Janeiro, Vol. 52, no 1, 2009, pp. 85 a 121. 
tanto regulem as condições da venda e do uso da força de trabalho quanto assegurem a fruição de bens relacionados à saúde, educação, habitação, alimentação, através do provimento público, além de garantir uma renda mínima às pessoas, quando o mercado falha ou não as absorve, representaria a utopia da completa desmercantilização ainda nos marcos da ordem capitalista.

Neste artigo, o objetivo é rastrear as condições em que o movimento sindical brasileiro buscou assegurar a desmercantilização da força de trabalho na trajetória do capitalismo no país, conectando-as à atitude que desenvolve em relação às diferentes modalidades de superpopulação relativa que são engendradas em meio àquela trajetória. A abordagem centra-se nas décadas de 1950, 1980 e 1990, períodos nos quais, dada a natureza aberta do sistema político, a ação sindical ganha visibilidade e os sindicatos são levados a se pronunciar sobre variados temas, inclusive acerca da política social.

As variáveis consideradas fio condutor da pesquisa que originou esta abordagem são: 1) a estrutura do mercado de trabalho; 2) as formas de organização prevalecentes no meio sindical;3) e o ambiente político no qual os sindicatos atuam e fazem suas escolhas. A primeira porque, ao mesmo tempo que registra as bases estruturais do poder de classe dos trabalhadores, salienta a natureza e a dimensão da superpopulação relativa em cada período. A segunda porque registra a moldura institucional da organização e da expressão da identidade dos trabalhadores, afetando o modo como eles se veem como ator social e a percepção que desenvolvem em relação a outros atores. Por fim, o ambiente político registra a presença (ou não) de outros atores que interferem nas formulações do movimento sindical e sua relação com o Estado.

Contudo, antes de passarmos à identificação da postura sindical e desses fatores em cada período, cumpre tecer algumas considerações a respeito da trajetória de formação das políticas sociais tal como apresentada pela literatura pertinente, buscando aquilatar a importância da organização dos trabalhadores na fixação de tais políticas, bem como a relevância dessas políticas para a desmercantilização da força de trabalho.

\section{DIREITOS SOCIAIS, AÇÃO COLETIVA E DESMERCANTILIZAÇÃO}

Desde Marshall (1967), a conquista dos direitos sociais tem sido tratada como corolário do processo de construção da cidadania. Assim 
compreendidas, as políticas sociais são consideradas pressuposto da democracia e, em certos casos, revelam-se um requisito fundamental para a estabilidade democrática. A ampliação da participação política que acompanha a instalação do regime democrático suscita, entre as camadas menos favorecidas da sociedade, expectativas de bem-estar. Nesse sentido, é essencial a presença de uma contrapartida institucional capaz de sistematizar essas expectativas e canalizá-las para o sistema político. Do contrário, tende a se estabelecer um quadro de instabilidade em função da ausência de resposta institucional às expectativas de bem-estar engendradas pelo processo de ampliação da participação política. Em outros termos, a ausência de políticas sociais amplamente aplicadas dificulta a formação do consenso em torno da democracia, introduzindo desafios importantes para a consolidação do regime democrático ${ }^{2}$.

Do ponto de vista dos trabalhadores, as políticas sociais são essenciais, ainda, por promoverem a desmercantilização da força de trabalho. Nessa medida, elas representaram uma inflexão, na trajetória das sociedades capitalistas, que conduziu à mercantilização do trabalho, de sorte que a sobrevivência e o bem-estar das pessoas passavam a depender progressivamente de relações monetárias ${ }^{3}$. A organização dos trabalhadores cumpriu um papel crucial na formulação de demandas direcionadas à fixação de políticas sociais e, por conseguinte, à desmercantilização da força de trabalho, em um processo que culminou com a afirmação do Estado de Bem-Estar Social em países da Europa Ocidental no pós-Segunda Guerra.

Em formulação que se tornaria clássica, Polanyi (1980) destaca a natureza fictícia do mercado de força de trabalho, o caráter utópico do liberalismo e a reação social suscitada pela transformação do trabalho em mercadoria. Historicamente, a utopia liberal seria superada com o advento e o desenvolvimento das políticas sociais, e o subsequente afrouxamento do caráter de exclusiva mercadoria que o desenvolvimento capitalista, em bases liberais, conferia à força de trabalho. Considerado um dos principais expoentes da abordagem institucional, Polanyi não atribuía centralidade ao papel desempenhado pelos agentes sociais no desencadeamento das políticas sociais e do Welfare State. No entanto, estudiosos de diferentes matizes enfatizaram a presença da organização dos trabalhadores no processo de formação do Estado de Bem-Estar Social, seja porque estes foram capazes de pressionar o poder público em direção à implementação de tais políticas, seja porque o Estado, 
em antecipação a uma suposta radicalização da ação ideologicamente enraizada dos trabalhadores, assegurou-lhes direitos sociais a fim de inibir uma mobilização que pudesse pôr em risco as bases do desenvolvimento capitalista ${ }^{4}$.

Atestando a importância dos trabalhadores na instituição de políticas sociais, Przeworski (1989) indica que a montagem do Welfare State na Europa Ocidental se deve à orquestração de um compromisso entre trabalhadores e empresários, no qual os primeiros renunciam à pretensão de subverter os fundamentos da economia capitalista - e mesmo à perspectiva de ganhos imediatos - a fim de garantir a continuidade da expansão econômica. Os empresários, por seu turno, admitem a instalação de uma ampla rede de benefícios e de serviços sociais assegurados pelo Estado, desde que garantidas a intocabilidade da propriedade capitalista e a preservação de ganhos adequados à manutenção de um ritmo de investimento elevado ${ }^{5}$. De sua parte, Esping-Andersen (1990) ressalta a importância da atuação dos trabalhadores não apenas no desencadeamento das políticas sociais mas também na formatação dos diferentes modelos de Estado de Bem-Estar Social, que, nos termos do autor, se condicionam, entre outros, ao grau de desmercantilização do trabalho que são capazes de promover. Trazendo a discussão para o Brasil, Santos (1979) destaca que os trabalhadores, ao se organizarem e reivindicarem direitos sociais, denunciam os caracteres mercantil do capitalismo e falacioso do contratualismo liberal, "determinando o desmascaramento de sua expressão mercantil e jurídica e revelando o seu conteúdo de exploração" (ibidem:23). A implementação de políticas sociais e a desmercantilização do trabalho caminharam, pois, lado a lado na construção do Welfare State, a despeito da forma que este tenha adquirido.

De todo modo, a fixação de políticas sociais produz o efeito, nem sempre desejado, de reduzir a dependência do trabalhador em relação ao empregador e termina por se transformar em fonte potencial de poder (Heimann apud Esping-Andersen, 1990:89), desencadeando um círculo virtuoso que tende a alimentar o processo de construção da cidadania baseada em direitos sociais e na desmercantilização da força de trabalho. Em outros termos, a desmercantilização fortalece o trabalhador e enfraquece a autoridade absoluta do empregador. Os direitos sociais, a igualdade e a erradicação da pobreza que um Estado de Bem-Estar universalista busca constituem pré-requisitos importantes para a força e a unidade necessárias à mobilização coletiva de poder (Esping- 
Andersen, 1990:95). Na presença de mecanismos de proteção referentes ao conjunto da sociedade, tais como seguro-desemprego, velhice, doença, acidente etc., trabalhadores emancipados em relação ao mercado se habilitam com mais facilidade à ação coletiva, fortalecendo a solidariedade de classe e ampliando as chances para o estabelecimento de uma sociedade menos desigual. Ao contrário, quando os trabalhadores se encontram em situação de inteira dependência em relação ao mercado, o custo da adesão à ação coletiva se eleva, inibindo o potencial mobilizador das organizações do trabalho. Nos termos de Esping-Andersen (ibidem:103), uma vez que os recursos dos trabalhadores espelham as desigualdades do mercado, surgem divisões entre os de dentro e os de fora, dificultando a constituição de movimentos reivindicatórios. Os trabalhadores constituem, dessa perspectiva, por mais de uma razão, a força mais interessada na implementação de políticas sociais universalistas e na desmercantilização do trabalho por elas induzida.

Portanto, as políticas sociais operam não apenas como instrumentos redistributivos; do ponto de vista dos trabalhadores, asseguram também a solidariedade de classe necessária à preservação de uma forte presença política desse ator.

De sua parte, a ação estatal, na regulação das relações de trabalho, dos processos de dispensa, bem como na proteção àqueles que se encontram fora do mercado de trabalho, por meio da legislação trabalhista e securitária, é, pois, fundamental para aumentar a segurança do trabalhador, o poder sindical e, assim, desonerar a participação na ação coletiva. Consideremos um instituto como o seguro-desemprego. Ao garantir condições de sobrevivência àqueles trabalhadores que são expelidos do mercado em suas variações cíclicas - ou mesmo como retaliação patronal pela participação em ações coletivas, ou ainda como estratégia para o rebaixamento dos salários -, ele dificulta que operem os elementos de desagregação na solidariedade dos trabalhadores provocados pela presença do que Marx designou pela noção de exército industrial de reserva, constituído a partir das inovações tecnológicas verificadas com o esgotamento da acumulação extensiva do capital. Assim, se a presença de um excedente de força de trabalho permanece indispensável para a continuidade do investimento capitalista, sua capacidade de afetar negativamente o comportamento dos salários é mitigada diante da redução da pressão que o desempregado exerce na disputa por vagas no mercado de trabalho ${ }^{6}$. 
O mesmo se poderia dizer de outros benefícios sociais promovidos pelo Estado e assegurados universalmente àqueles que, por alguma razão - doença, acidente, velhice, invalidez para o trabalho, carência de vagas -, se encontram fora do mercado de trabalho. A presença de vastos contingentes fora do mercado e sem proteção assegurada por políticas sociais aumenta a insegurança dos de dentro, tornando-os mais suscetíveis às imposições do capital, cuja lógica tende a se pautar pelas condições do mercado. Grosso modo, pode-se dizer que, quanto maior for a abrangência das políticas sociais, menos mercantilizada será a força de trabalho. Dessa forma, no processo de desmercantilização, são importantes não apenas as leis trabalhistas mas também as políticas sociais em geral. Em outros termos, a desmercantilização ocorre quando a prestação de serviços é concebida como um direito social, ou seja, quando tais serviços não precisam ser adquiridos no mercado. Isto é, quando a sobrevivência e o bem-estar das pessoas não estão condicionados à venda de sua força de trabalho no mercado.

Por outro lado, a realização de um Estado de Bem-Estar supõe um vasto contingente inserido no mercado de trabalho, tanto para reforçar um mercado interno de consumidores quanto para assegurar um volume de contribuições - a despeito do formato que estas venham a assumir-, capaz de proporcionar a oferta de serviços de boa qualidade.

Um mercado de trabalho amplo e inclusivo fortalece a ação coletiva direcionada à obtenção de benefícios universais, o que tende a contribuir para a redução de manifestações corporativistas e individualistas. Ao contrário, quando a massa de desempregados atinge um volume críti$c o$, acentua-se a pressão do exército de reserva sobre os trabalhadores em atividade, fragilizando a proteção a esses setores, com impacto sobre a maneira de se defender dos assalariados. A parcela protegida do mercado de trabalho tende a se desestabilizar na presença de um vasto contingente de desempregados, gerando, nos termos de Brunhoff (1991:93), atitudes de "salve-se-quem-puder" que atentam contra as formas coletivas de organização e ação. Desse modo, políticas de geração de empregos configuram uma contrapartida importante das políticas sociais no plano da economia, contribuindo para aumentar a disposição para agir dos trabalhadores e para a obtenção de novas conquistas sociais. Em boa medida, políticas de pleno emprego e compensações pelo funcionamento inadequado do mercado, assegurando níveis elevados de solidariedade entre os trabalhadores, revelaram-se instrumentos cruciais nos arranjos que possibilitaram a compatibilização 
entre expansão industrial e ampliação da rede de proteção social nos países de economia central; entre capitalismo e democracia, portanto.

\section{CONSIDERAÇÕES PRELIMINARES ACERCA DO CASO BRASILEIRO}

Tomando por base as considerações anteriores, cumpre indagar em que medida essa situação é diversa quando têm peso na estrutura social contingentes de pessoas que se ligam marginalmente ao mercado de trabalho, pressionando os trabalhadores nele ocupados, sem que sua presença resulte da exaustão da acumulação extensiva do capital, isto é, sem que apareçam como um fenômeno cíclico da operação do mercado capitalista. Tal indagação se revela crucial para o estudo das relações estabelecidas entre o movimento sindical e as políticas sociais no âmbito da industrialização retardatária e periférica, em que os processos de inovação tecnológica guardam pouca relação com o esgotamento da reserva de força de trabalho, antes se efetuando pela aquisição de equipamentos no mercado mundial.

No Brasil, a transição rural-urbana, pelo menos em suas fases iniciais, realiza-se constituindo amplos contingentes ocupados em pequenos serviços, na medida em que o crescimento de postos de trabalho gerados no mercado formal não é capaz de absorver tais segmentos da população ${ }^{7}$. Nesse contexto de acelerada transição demográfica, configura-se um quadro dicotômico em que um restrito mercado formal contrasta com um volumoso mercado informal; o trabalho organizado, protegido e estável contrasta com o desorganizado, desprotegido e instável, tendência que parecia reverter-se nos anos 1970 e 1980, mas que findou por acentuar-se na década de 1990, como destacou Mattoso (1995). Nesse quadro, políticas compensatórias, como o seguro-desemprego, podem revelar-se insuficientes para assegurar a desmercantilização do trabalho, porque dizem respeito apenas àquelas pessoas que se encontram temporariamente fora do mercado formal.

Na presença de um vasto contingente de pessoas que se ligam marginalmente ao mercado de trabalho, os trabalhadores podem ser levados a formular reivindicações, em torno de medidas regulatórias e preventivas, que sejam capazes de ampliar o acesso ao mercado formal e, por conseguinte, à proteção social vinculada à formalização do trabalho, ainda que tais demandas sejam motivadas pelo desejo de ampliar a segurança no emprego dos próprios trabalhadores formais e o poder do trabalho em face do capital. 
Nesse ponto, cumpre lembrar que as políticas sociais no Brasil foram vinculadas, desde os anos 1930, à inserção do indivíduo no mercado formal de trabalho, configurando um estado de bem-estar ocupacional (Sposati, 1995), sob o imperativo da cidadania regulada (Santos, 1979), assertiva que deve ser adicionada como ingrediente básico especialmente quando analisamos a postura do movimento sindical nos anos 1950, momento em que o mercado formal esteve longe de abranger a totalidade da População Economicamente Ativa (PEA) nacional e a política social se limitava, por conseguinte, a uma pequena parcela da população, de modo que a desmercantilização da força de trabalho no Brasil supunha, em boa medida, a superação da cidadania regulada.

Partindo dessas considerações, buscaremos indicar, doravante: 1) em que medida a estrutura do mercado de trabalho e a presença de contingentes que não se engajam no mercado formal afetam a percepção dos setores protegidos acerca das políticas sociais - sua extensão e natureza - nas condições brasileiras; 2) qual é a influência que a estrutura organizacional dos atores exerce nesse processo e em que medida os trabalhadores organizados buscam superar a estrutura corporativa para além dos aspectos organizacionais, elegendo pautas e definindo agendas que extrapolem os interesses diretamente relacionados à categoria profissional da qual fazem parte, traçando estratégias mais abrangentes, que digam respeito ao conjunto dos setores populares, inclusive os que se encontram fora do mercado de trabalho; 3 ) em que medida o ambiente político nacional afeta as escolhas do movimento sindical.

\section{MERCADO, SINDICATOS E POLÍTICA NOS ANOS 1950}

Na década de 1950, verifica-se um intenso crescimento da economia nacional, que repercute no perfil da população brasileira. Segundo divisão proposta por Baltar e Dedecca (1992), esse período corresponde à terceira etapa da formação do mercado de trabalho no Brasil ${ }^{8}$, quando o padrão de acumulação resultante da industrialização pesada induz à consolidação do mercado de trabalho urbano.

No entanto, a imagem otimista que se tinha acerca do potencial de absorção do mercado de trabalho era embaçada pela presença de um volume crescente de trabalhadores informais, tendo em vista que o ritmo de crescimento da população urbana era sensivelmente superior à criação de vagas no mercado formal de trabalho. Quanto à criação de vagas na indústria de transformação, mola propulsora do crescimento 
econômico no período, o quadro apresentava-se ainda mais severo: se a PEA ocupada nesse setor correspondia a 1.608,3 milhão de pessoas em 1950, em 1960 esse número aumentava para apenas 1.954,1. Em termos percentuais, verifica-se um decréscimo da parcela da PEA ocupada na indústria de transformação, de 9,4\% em 1950 para 8,6\% em 1960 (Lobo, 2005). Assim, a criação de novos empregos nos anos 1950 ficava a cargo, especialmente, do setor de serviços e, mais particularmente, do subsetor de serviços pessoais e do pequeno comércio, que cresciam em bases precárias, com baixa densidade de capital, baixa rentabilidade, nível inadequado de desenvolvimento legal e institucional, instabilidade ocupacional e baixos salários (Faria, 1986).

Esse quadro se reflete nos indicadores de formalização do mercado de trabalho, que apresenta trajetória declinante entre 1950 e 1960. Tomando por base o número de contribuintes ativos para a Previdência Social em 1950 e 1960, e contrastando-o com os indicadores referentes à PEA urbana, constata-se que em 1950 havia 45,63\% da PEA urbana inserida no mercado formal de trabalho, ao passo que em 1960 essa taxa declina para $42,76 \%$.

Tendo em vista a modernização da indústria tradicional, somada à baixa capacidade revelada pelas indústrias dinâmicas de absorver força de trabalho na proporção em que esta é gerada, forjam-se, nos principais centros industriais do país, massas desempregadas ou subempregadas desprovidas de direitos sociais, de capacidade adequada de consumo e, fundamentalmente, de tendência associativa ${ }^{10}$. O que se verifica é, pois, a formação de uma população excedente para além do exército industrial de reserva, cuja presença tende a acentuar a ação despótica do capital sobre o trabalho e a definição, pelo mercado, das regras de contratação e uso do trabalho. É provável que isso tenha contribuído para que os trabalhadores priorizassem uma agenda direcionada à preservação de seus direitos e à manutenção do poder aquisitivo dos salários, em detrimento de ações direcionadas à superação da cidadania regulada.

No que diz respeito ao ambiente político, o período que se estende de 1946 a 1964 foi, durante muito tempo, tratado como um simulacro de ordem democrática, seja pela interdição à presença na cena política nacional de forças como o Partido Comunista Brasileiro (PCB), seja pela preservação da estrutura sindical corporativa, seja pela fragilidade do sistema partidário e da representação política. Essa imagem, en- 
tretanto, tem sido revista. Não obstante a exclusão do PCB, efetivamente uma medida não democrática, o sistema partidário brasileiro de 1946 a 1964 parecia seguir uma trajetória de crescente consolidação (Lavareda, 1991), enquanto a estrutura corporativa cumpria papel ambíguo para a mobilização dos trabalhadores (Lobo, 2005). De qualquer forma, apenas durante o governo Dutra o Estado recorreu de maneira intensa à prerrogativa de intervir nos sindicatos, de modo que a ação destes, na maior parte do período, foi marcada de razoável e progressivo grau de autonomia e combatividade ${ }^{11}$.

Todavia, nos anos 1950, os sindicatos dispunham de visibilidade crescente em um cenário político marcado pela ausência - ou pelo caráter ainda muito incipiente - de outros movimentos sociais ${ }^{12}$. Em face da ausência, na cena política, de outros atores de extração popular com os quais os trabalhadores pudessem se aliar, é possível indicar que não havia incentivos de natureza política para que os trabalhadores formais reivindicassem medidas orientadas para a superação da cidadania regulada, por meio da extensão da política social aos segmentos situados à margem do mercado formal de trabalho, diferentemente dos anos 1980, como veremos adiante. Por outro lado, também não havia constrangimentos à adoção de uma pauta restritiva, voltada para a defesa do aprimoramento de políticas para o universo inserido no mercado formal, tal como, de certa forma, se verifica nos anos 1990.

Nesse ponto, o papel desempenhado pelos atores na constituição da cidadania adquire relevo e nos remete às análises de De Swaan (1988). O autor sugere que as modernas políticas sociais se desenvolvem dentro de uma figuração de quatro lados envolvendo o Estado, os trabalhadores assalariados, o empresariado e os pequenos proprietários. A ação do primeiro depende das coalizões que o sustentam, enquanto os trabalhadores assalariados seriam a principal força para reivindicar as modernas políticas sociais. A perspectiva empresarial, por seu turno, seria balizada pelo impacto das políticas sociais para o desempenho das empresas, o que confere peso à forma como as economias nacionais se inserem no mercado mundial e ao tipo de tributação que sustenta os aparatos públicos de política social ${ }^{13}$. De sua parte, os pequenos proprietários, especialmente trabalhadores autônomos em atividades craft, seriam, segundo De Swaan, uma força que opõe resistência à instalação das modernas políticas sociais, por verem nelas uma forma de recompensa que desconsidera o mérito. Seu peso na estrutura social francesa, por exemplo, teria representado um fator relevante para 
explicar o ritmo relativamente lento da implementação do Estado de Bem-Estar Social naquele país.

É pouco provável que tal papel - de interdição política e ideológica à instalação das modernas políticas sociais - fosse cumprido pela grande massa de trabalhadores autônomos ocupados em pequenos serviços urbanos ao longo do processo de industrialização brasileira. Ao contrário dos pequenos proprietários assinalados por De Swaan, no caso europeu, eles não constituíam um contingente representativo de atividades tradicionais que a dinâmica capitalista fez erodir progressivamente. De fato, ocupavam atividades precárias no setor de serviços, criadas com o processo de industrialização, dado o caráter desigual deste, conforme mencionamos. Dessa forma, aspiravam às ocupações modernas inclusive para alcançarem os benefícios à disposição das pessoas que estavam dentro do mercado formal e da cidadania regulada. Para os trabalhadores assalariados, contudo, sua incorporação poderia representar um rebaixamento dos benefícios percebidos, mantidas as formas de custeio das políticas sociais. Assim, propugnavam, fundamentalmente, que o acesso do contingente situado à margem do mercado formal às políticas sociais se processasse por sua incorporação ao próprio mercado formal, por meio do incremento do processo de industrialização.

Do ponto de vista organizacional, é possível indicar que, na democracia de 1946, embora os trabalhadores estivessem organizados a partir da estrutura sindical corporativa e jamais tenham logrado - ou mesmo buscado - derrubar efetivamente os pilares que sustentavam a instituição, como a unicidade e o imposto sindical ${ }^{14}$, esta se despiu de certos traços impressos em sua origem. Dessa forma, se no contexto autoritário do Estado Novo os sindicatos da estrutura oficial constituíam instrumentos de controle do Estado sobre os trabalhadores, a partir de 1943, quando a ditadura estadonovista começa a se dissolver, os trabalhadores se apropriam progressivamente da estrutura montada pelo Estado e a transformam em locus de formulação de demandas e de mobilização ${ }^{15}$. Assim, em que pesem os efeitos acomodativos que a unicidade e o imposto tendiam a provocar entre as lideranças sindicais (Lobo, 1995), os sindicatos oficiais tornavam-se organismos que, mesmo que não dispusessem de forte enraizamento nas bases, eram capazes de mobilizá-las para a ação coletiva na defesa de seus interesses, como atestam os indicadores de participação em atividades grevistas ${ }^{16}$. 
Além disso, ainda que o sindicato oficial fosse o único canal de intermediação de interesses reconhecido pelo Estado, no ambiente democrático dos anos 1950, a estrutura sindical já não era capaz de encapsular a ação coletiva, cada vez mais intensa no período. Com efeito, organizações de base e experiências intersindicais, que escapavam ao formato verticalizado da estrutura corporativa, começavam a despontar, dividindo com os sindicatos a tarefa de mobilizar os trabalhadores. Contudo, durante o governo Kubitschek, a presença do formato corporativo, inclusive no que diz respeito aos benefícios previdenciários, ainda segmentava a ação coletiva dos trabalhadores por categoria profissional, ao mesmo tempo que se preservava o hiato entre os interesses dos trabalhadores formais e informais, ainda que, particularmente no início dos anos 1960, as greves de massa motivadas pela defesa de temas mais abrangentes, que afetavam inclusive os que estavam fora do mercado formal, adquirissem relevância.

Portanto, na década de 1950, não havia incentivos nem pelo lado da economia nem pelo lado da política para que o movimento sindical formulasse pautas inclusivas, orientadas para a superação da cidadania regulada. Da ótica sindical, a desmercantilização do trabalho supunha, sobretudo, a intensificação do processo de industrialização para aumentar o acesso ao mercado formal de trabalho e, por conseguinte, aos benefícios da cidadania. Embora o tema da previdência fosse central na agenda sindical, os trabalhadores tendiam a adotar uma postura defensiva, orientada para a manutenção dos benefícios conquistados pelos segurados dos institutos. Em alguns casos, reivindicava-se a isonomia de direitos dentro desse universo, conquistada com a promulgação da Lei Orgânica da Previdência Social no fim da gestão presidencial de Kubitschek e início da década seguinte. A partir daí, intensifica-se a defesa de reformas mais abrangentes, a exemplo da Reforma Agrária, a qual poderia conter o crescimento de uma população urbana que não se integrava ao mercado de trabalho e que, em um ambiente de crise, pressionaria para baixo os salários, com a subsequente deterioração do padrão de vida dos trabalhadores urbanos com vínculos formais, tal como aparece de modo explícito em diversos documentos sindicais publicados no período (Lobo, 2005).

\section{MERCADO, SINDICATOS E POLÍTICA NOS ANOS 1980}

Nos anos 1980, o cenário se modifica. A transição rural-urbana da população brasileira já se havia completado, e o mercado urbano de força 
de trabalho se revela mais inclusivo. A conclusão do processo de transição demográfica, bem como o sucesso dos processos de industrialização - dentro do paradigma fordista - e de modernização do campo, reduzia a presença dos contingentes marginalizados da população urbana.

Não obstante a interrupção que se verifica no processo de crescente assalariamento e de formalização da estrutura ocupacional, o desemprego aberto só foi expressivo no período recessivo do início da década. No fim dos anos 1980, o mercado de trabalho brasileiro apresentava taxas de desemprego aberto bastante reduzidas (Baltar, Dedecca e Henrique, 1996), alcançando em 1989 o menor índice do decênio. A elevada capacidade de absorção do mercado de trabalho decorria de fatores como: redução do ritmo de crescimento da PEA urbana, em contraste com o período precedente, tornando possível sua absorção nas atividades urbanas; elevação do emprego no setor público, particularmente em atividades sociais; resistência dos principais agentes econômicos às reformas liberalizantes, que se processariam no Brasil apenas na década seguinte (ibidem; Fiori e Tavares, 1993; Mattoso, 1995). Por outro lado, a não ocorrência de uma ampla reestruturação do aparelho produtivo possibilitou, nos períodos de retomada da atividade econômica, o reemprego da força de trabalho que havia sido expelida do mercado no ciclo recessivo (Baltar, Dedecca e Henrique, 1996).

O mercado de trabalho no período notabiliza-se, pois, por elevados indicadores de formalização, os quais, combinados ao processo de transição política, transformavam a década perdida em uma conjuntura de certo otimismo nos meios sindicais, em que se desenvolvia a expectativa de superação do caráter fortemente mercantilizado que assumira a força de trabalho no país e da cidadania regulada, já mitigada pela universalização de certas políticas sociais.

Por outro lado, uma das características mais marcantes do mercado de trabalho nos anos 1980 é a rotatividade de mão-de-obra, a qual se revela extremamente elevada não apenas em um contraste com países de industrialização mais antiga, mas mesmo em comparação com outros países do subcontinente ${ }^{17}$. A despeito de suas causas, há de se salientar que índices elevados de rotatividade, além de serem indicativos de uma legislação incapaz de impor freios às demissões arbitrárias, provocam uma extrema fragilização do trabalhador em face do empregador. Em outros termos, elevada rotatividade conduz à precarização 
dos postos de trabalho e reduz o poder de barganha do trabalho diante do capital. Werneck Vianna há muito salientou, com base na visão dos próprios empresários, que a "estabilidade no emprego aumenta o passivo trabalhista das empresas, diminuindo suas possibilidades de ação" (1999:344). A elevada rotatividade, ao contrário, subtrai poder do trabalho e tende a reduzir a capacidade de mobilização dos sindicatos, configurando, assim, um fator de peso que tende a reforçar o caráter mercantilizado do trabalho.

Contudo, a despeito das elevadas taxas de rotatividade, o tempo de espera por novo emprego era reduzido nos anos 1980, sobretudo quando contrastado com os indicadores dos anos 1990. Além disso, na ausência de reestruturação industrial, o retorno à categoria de origem era bastante provável, poupando-se assim as bases sociais dos sindicatos. Dessa forma, não obstante a elevada rotatividade contribuir sobremaneira para acentuar o caráter mercantil da força de trabalho, a vasta oferta de vagas, ao permitir um rápido retorno ao mercado de trabalho, anulava, ainda que parcialmente, o impacto da rotatividade no processo de mercantilização, favorecendo a difusão de disposições universalistas nos meios sindicais.

Em outras palavras, a superpopulação relativa, presente na estrutura capitalista da economia brasileira dos anos 1980, já não corresponde a um vasto contingente que o desenvolvimento econômico é incapaz de absorver, como nos anos 1950; menos ainda a um grupo de pessoas permanentemente expelidas do mercado de trabalho, por força de um processo de acumulação regido pela reestruturação das empresas e pela emergência de um novo paradigma tecnológico, que se vale cada vez menos de trabalho vivo, como nos anos 1990. Trata-se de um contingente que pertence às fileiras assalariadas e que delas se ausenta ciclicamente, contribuindo para que a agenda sindical contemple os interesses dos excluídos do mercado formal de trabalho.

Na política, o cenário é marcado pela efervescência social, expressa no surgimento dos novos movimentos sociais, parceiros potenciais do movimento sindical. Com efeito, em meio ao processo de transição política, a mobilização social não se restringiu ao trabalho. Segundo Boschi (1987), dos campos, dos bairros, das favelas, organizavam-se e lançavam-se à cena política outros movimentos, populares ou de classe média, muitos deles apoiados por entidades da sociedade civil egressas de setores da Igreja Católica ou por agrupamentos ecumênicos, inte- 
lectuais etc. Por seu turno, entre os assalariados, a mobilização ultrapassou as fronteiras do movimento operário, atingindo a classe média, conforme atesta a organização de profissionais liberais e funcionários públicos.

Quanto às demandas dos grupos que compõem esse renascimento da sociedade civil, que marca a saída do último ciclo autoritário, verifica-se uma conjugação de questões especificamente relacionadas aos interesses particulares de cada segmento com a pressão por liberdade e igualdade, ponto que unificava os diversos movimentos. A mobilização desses setores contribuirá para que, na década de 1980, a sociedade brasileira abra uma série de oportunidades à democracia tanto em seu aspecto político quanto no campo mais substantivo da superação do abismo socioeconômico que separa o país em duas realidades. A forte mobilização em torno da campanha pelas eleições diretas para presidente, a articulação de demandas direcionadas ao Congresso Constituinte, a mobilização em torno da candidatura de Luiz Inácio Lula da Silva à presidência, em 1989, simbolizam algumas dessas oportunidades (Rodrigues, 2001). Em todos esses episódios, a institucionalização da democracia dividia espaço com as expectativas de superação das profundas divisões socioeconômicas que marcavam desde sempre a sociedade brasileira. Era essa combinação que suscitava novas organizações e articulações que revitalizaram a cena política do período, em um círculo virtuoso no qual mobilização e institucionalização pareciam alimentar-se mutuamente.

Segundo Rodrigues (ibidem), a organização e a ação desses grupos se davam, pois, nos marcos de um campo ético-político que combinava a rejeição ao autoritarismo, que havia marcado o regime que combatiam diretamente, com a negação do padrão corporativo-clientelista que teria predominado no período anterior. É nessa perspectiva que os novos atores buscam superar os limites da competição intraelites e reinstaurar o eixo da participação, mas também a luta pela redistribuição ${ }^{18}$. Nos termos de Mota (1995:151),

o horizonte ideológico e político dessas lutas é o da autonomização das condições de reprodução do trabalhador diante da esfera da reprodução econômica do capital. No plano material, o horizonte dessa luta projeta-se na esfera do consumo coletivo de bens e serviços não mercantis, cujo acesso, pelos trabalhadores, não dependeu, exclusivamente, do tempo de trabalho fornecido ao capital, pelo fato de muitos desses bens não se vincularem ao poder de compra dos salários [...]. No 
plano jurídico-político, a mediação daquele processo se fez pela institucionalização dos direitos políticos e sociais, fundados nas necessidades do trabalho e não nas necessidades da venda da força-de-trabalho.

Assim, nos anos 1980, havia incentivos tanto pelo lado da economia quanto pelo lado da política para que os trabalhadores organizados assumissem um discurso orientado para a proteção aos excluídos do mercado formal de trabalho por meio da universalização da cidadania.

Quanto à organização sindical, a despeito do retorno ao ordenamento corporativo que as antigas oposições sindicais elegerão como estratégia no momento imediatamente posterior ao recrudescimento do sindicalismo, a autonomia que marca seus primeiros passos será fundamental para a aproximação que busca estabelecer com os novos movimentos sociais e para a definição de suas escolhas e de sua agenda ${ }^{19}$. Essa disposição para uma luta conjunta existe desde a formação da CUT e teria sido, de certo modo, determinante do ritmo que assumia a transição para a democracia, ao mesmo tempo que tornava o quadro pleno de incertezas, sobretudo no que tange à questão social ${ }^{20}$.

Por outro lado, conquanto permanecesse em aberto a solução para o secular problema das desigualdades sociais - o que de certa forma implicava a superação da cidadania regulada por meio da inclusão dos setores que até então vinham sendo mantidos à margem dos direitos sociais, os quais, na clássica formulação marshalliana, constituem o corolário do processo de universalização da cidadania -, na política avançava-se firmemente em direção à democracia ${ }^{21}$.

Na esfera do sistema político, a reforma de 1979 abria caminho para a organização partidária dos trabalhadores ${ }^{22}$, permitindo o estabelecimento de vínculos mais consistentes entre o movimento sindical, demais movimentos sociais e a representação parlamentar. Em certa medida, o PT buscava cumprir, na esfera institucional, o papel de representante dos interesses dos trabalhadores, assumindo progressivamente a função de dissolver os interesses corporativos e de organizar pautas mais abrangentes, que correspondessem a reivindicações comuns a várias categorias (Mota, 1995:153). Além disso, o partido buscava tornar-se interlocutor também dos demais setores populares, fixando uma agenda que extrapolava demandas referentes especificamente aos trabalhadores formais e refletindo os interesses definidos pelos diversos setores organizados em suas bases, sob a forma de núcleos de moradia, de "minorias" etc. ${ }^{23}$ 
No campo estritamente sindical, a emergência e a afirmação das centrais sindicais aumentavam a visibilidade das correntes presentes dentro do sindicalismo e de certo modo homogeneizavam as demandas, favorecendo um tratamento não corporativo das questões que afetavam o conjunto dos trabalhadores e também os outros setores populares. Segundo Mota, os trabalhadores teriam logrado ampliar significativamente seu campo de reivindicações, inclusive "por meio de propostas encaminhadas pelas centrais sindicais e pelos partidos políticos, de natureza mais universal, e que abriam espaço para a institucionalização de novos direitos políticos e sociais" (ibidem:151), ao mesmo tempo que, nos contratos coletivos de trabalho, obtinham benefícios específicos relacionados às condições de trabalho, produtividade e benefícios sociais junto às empresas.

De certa maneira, como que em uma divisão de tarefas, os sindicatos oficiais, reapropriados pelos trabalhadores, realizavam greves localizadas e se concentravam nas campanhas salariais, no âmbito das quais defendiam interesses específicos dos empregados de uma empresa ou dos membros de determinada categoria profissional, enquanto as centrais - ou a central, para ficarmos no âmbito da CUT ${ }^{24}$ - e os partidos mais precisamente o PT, mas não apenas ${ }^{25}$ - se lançavam na luta política pela extensão das conquistas obtidas pelas categorias mais organizadas ao restante dos trabalhadores e pela extensão de conquistas que historicamente eram atribuídas apenas aos trabalhadores com vínculos formais ao conjunto dos setores populares. Essa perspectiva se reflete na defesa da fixação constitucional de direitos aos trabalhadores domésticos, rurais, pescadores e avulsos, ponto essencial no embate que se trava, durante a Constituinte, entre os partidos progressistas e o chamado centrão $0^{26}$.

De todo modo, o que importa marcar até aqui é que, nesse contexto, a emergência política de novos atores, associada à renovação do movimento sindical, força o estabelecimento de um novo campo ético-político que permite a constituição de redes sociais a partir das quais emanam discursos e práticas que pressionam não apenas pela abertura à participação política dos de baixo (Rodrigues, 2001) mas também pelo debate em torno da questão social. Da mesma forma que na política se apontava para a superação não apenas da ordem autoritária mas também da institucionalidade corporativa que antecede o regime militar, na questão social, buscava-se a ruptura com a segmentação e a exclusão que marcam a política social desde sua instauração, entre as 
décadas de 1930 e 1940, e que as alterações subsequentes não lograram superar.

Assim, a defesa da incorporação à cidadania via inserção no mercado formal, presente no discurso do movimento sindical nos anos 1950, será de certo modo ultrapassada no ocaso do desenvolvimentismo, dando lugar a formulações direcionadas à universalização dos benefícios previdenciários e à luta em favor da adoção de políticas regulatórias e compensatórias, de geração de empregos e de proteção ao desempregado, essenciais no processo de redução do caráter mercantilizado das relações de trabalho. No limite, pois, o que se buscava nos anos 1980 era a superação da cidadania regulada, e não mais seu alargamento, como nos anos 1950.

\section{MERCADO, SINDICATOS E POLÍTICA NOS ANOS 1990}

As expectativas geradas nos anos 1980 dissolvem-se na década seguinte, diante do aparecimento do desemprego estrutural e de longa duração. No fim dos anos 1990, após uma década de políticas econômicas de estabilização monetária, o Brasil notabilizava-se por sua posição de país campeão mundial de desigualdades sociais e com uma economia marcada por reduzidos níveis de crescimento. Tal condição era inimaginável nos anos 1950, quando o país parecia apontar para a prosperidade e a inclusão social, via crescimento econômico e ampliação do mercado formal de trabalho. De certa forma, esse quadro era impensável também em meados dos anos 1980, quando a Comissão Econômica para a América Latina e o Caribe (Cepal) prognosticava que o Brasil dispunha de grandes chances de recuperar bons ritmos de crescimento (Soares, 1999:158) e as políticas sociais caminhavam em direção à universalização.

Na década de 1990, o desemprego, que já vinha se transformando em um problema mundial desde pelo menos os anos 1980 - quando os ciclos de crescimento das economias nacionais já não se faziam acompanhar da reposição de postos de trabalho, em função da reestruturação produtiva adotada de modo generalizado pelas empresas -, atinge em cheio a sociedade brasileira, alcançando mais de 10 milhões de pessoas em todo o país (Mattoso, 1995). O emprego com registro em carteira, por seu turno, que em 1989 correspondia a 59,5\% do total de ocupados no país, caiu para menos de 45\% em 1999 (idem, 1999). 
O fato é que o descontrole da inflação e o forte endividamento externo, dois aspectos centrais que o desenvolvimento mantido à marcha forçada envolvia, suscitavam a necessidade de redefinição das fontes de financiamento para a retomada do desenvolvimento industrial da nação. Quanto a isso, não parecia haver objeções relevantes entre os economistas. A percepção de que o país vivia uma profunda crise de ordem macroeconômica e um esgotamento do padrão desenvolvimentista era consensual ${ }^{27}$. A terapia adotada, contudo, foi objeto de controvérsias na medida em que tendia a produzir efeitos colaterais de monta sobre a sociedade brasileira, agravando celeremente o problema do desemprego no país.

Com efeito, a ênfase atribuída a uma agenda econômica centrada na estabilização monetária, que envolvia políticas recessivas, acabou conduzindo à desestruturação do setor produtivo e, por conseguinte, ao aumento do desemprego e da informalidade, enquanto permaneciam elevados os indicadores de concentração de renda e de riqueza. A absorção do receituário do Fundo Monetário Internacional (FMI) e de outros organismos multilaterais - receituário expresso no chamado Consenso de Washington - lançou o país em uma rota que terminou por tornar mais significativo o fenômeno da exclusão social. Por outro lado, como parte de um conjunto de medidas de desregulamentação e redução do Estado, o Executivo federal empenhou-se na defesa da flexibilização das relações de trabalho, reduzindo direitos e proteções aos trabalhadores formais.

No agregado, essas medidas resultaram na precarização do trabalho, fenômeno que, somado ao crescente desemprego, atingiu os sindicatos e o movimento sindical de diferentes maneiras, não apenas por causa da redução de suas bases - fator que, além de subtrair poder de barganha e pressão dos sindicatos, diminui as receitas sindicais -, mas também pela insegurança que o desemprego proporciona entre aqueles que permanecem empregados, com a subsequente redução da disposição para a participação em ações coletivas, cujos custos se elevam com a dilatação do contingente de desempregados. Ademais, a reestruturação produtiva e organizacional das empresas, chamadas a aumentar sua competitividade em função da abertura comercial, ao instituir os chamados programas de qualidade, força a lealdade do trabalhador em face da empresa, em detrimento do sindicato ${ }^{28}$, ao mesmo tempo que o fenômeno da terceirização pulveriza a força de trabalho, dificultando 
uma ação concertada desses trabalhadores, com impacto sobre a capacidade de mobilização dos sindicatos e também sobre sua agenda.

Quanto à presença de outros atores de extração popular na cena políti$\mathrm{ca}$, com os quais o movimento sindical pudesse estabelecer alianças em nome de uma pauta que extrapolasse demandas orientadas especificamente pelo interesse dos trabalhadores formais, o que se verifica nos anos 1990 é que, não obstante a mobilização de movimentos de diferentes matizes dispostos a reagir ao desemprego e à acentuação da exclusão, esses movimentos não chegaram a acumular forças que os habilitassem a pressionar o redirecionamento das políticas públicas, ainda que, em certos momentos, tenham logrado vetar certos projetos de contrarreforma da política social. Nesse período, a principal novidade política e social do cenário brasileiro foi o aparecimento do Movimento dos Trabalhadores Rurais Sem Terra (MST) (Linhares e Silva, 1999), cujo impacto sobre a agenda governamental se exprime nos inúmeros assentamentos promovidos. No discurso do MST, estavam presentes a rejeição ao neoliberalismo, a defesa de uma maior intervenção do Estado na economia e a "integração de uma parcela dos excluídos ao processo de cidadania", que só seria alcançada por meio do acesso à terra (ibidem:207). De imediato, defendiam uma reforma da estrutura agrária capaz de promover rápida e sistematicamente o assentamento das famílias de trabalhadores sem terra. Quanto à relação com o movimento sindical, o MST mantinha uma "proximidade crítica" com a CUT, repelia o "engajamento na cooperação com o governo da Força Sindical" e divergia da postura moderada da Confederação Nacional dos Trabalhadores na Agricultura (Contag), que defendia a "via legal e institucional para conquistas sociais para os trabalhadores rurais e agricultores" (Nogueira, 2000:9).

Na cena nacional dos anos 1990, observam-se, ainda, formas variadas de protesto, sobretudo na segunda metade da década. Embora já não se verifique a efervescência social que marcou o período de transição política na década anterior, destacam-se manifestações diversas relacionadas ao tema do desemprego e da exclusão social. O Grito dos Excluídos, a Marcha dos Cem Mil, o Grito da Terra Brasil, a Marcha Zumbi dos Palmares, a Marcha da Educação são exemplos de manifestações destinadas a protestar contra os efeitos da política governamental e a pressionar o governo no sentido de incluir na agenda a questão social. O movimento sindical, particularmente a CUT, envolveu-se diretamente em todas essas manifestações. Na perspectiva de uma CUT Ci- 
dadã ${ }^{29}$, tratava-se de empreender uma "resistência propositiva ao neoliberalismo e da necessária vinculação dos interesses dos trabalhadores assalariados do 'setor formal da economia' com os interesses mais amplos da classe trabalhadora e do povo oprimido" (CUT, 2000:9). O Fórum Nacional de Lutas, frente social que congregava movimentos de moradia, partidos políticos, sindicatos etc., foi resultado de um esforço conjunto que resultou na realização daquelas manifestações, as quais, contudo, dispunham de um caráter mais pontual do que permanente.

De qualquer forma, essas ações conjuntas resultavam da constatação de que enfrentar capital e governo exigia um esforço de todos os movimentos populares no sentido de aliar-se para combater e alterar "o modelo econômico excludente" (Stédile apud Nogueira, 2000:9). Nos termos da CUT (2000:9), tratava-se de combinar a "luta institucional às lutas de massa", agregando à pauta sindical "elementos essenciais para a conquista da plena cidadania [...], construindo uma política de aliança com o movimento social [...] para forjar uma alternativa ao governo neoliberal e suas políticas". Havia, portanto, por parte das lideranças dos movimentos sociais, exata noção das dificuldades a serem enfrentadas e da necessidade de se empreender uma ação concertada, passando da resistência - que aquelas manifestações a que aludimos acima exprimiam - à proposição de um projeto nacional que viabilizasse a consecução das diretrizes impressas na Constituição em matéria social e as aprofundasse.

No entanto, o discurso desregulamentador emanado do governo federal e de organismos empresariais enfatizava as divisões entre os trabalhadores inseridos no mercado formal e os de fora, além de acentuar a cisão no interior do próprio movimento sindical. Ao insistir na tese de que o desemprego era tributário do elevado custo da contratação formal e de que a solução se vinculava à supressão de direitos aos trabalhadores formais, o discurso governamental lançava água no moinho da remercantilização da força de trabalho no país. Por outro lado, a presença pontual daqueles movimentos inibia a efetivação de alianças mais persistentes e a fixação de um elenco de políticas sociais que permitissem a construção de laços amplos de solidariedade capazes de garantir os contramovimentos de autodefesa da sociedade diante do acentuado processo de desestruturação do mercado de trabalho. 
Portanto, o desafio era de monta e enfrentá-lo implicaria estender a ação sindical para além do mundo do trabalho, de certo modo recobrando o papel que o sindicalismo exerceu nos anos 1980, ao transformar-se em protagonista do processo de aprofundamento da democracia e de transformações sociais, em direção à universalização da cidadania ${ }^{30}$. No entanto, isso dependia não só da mobilização de outras forças que oferecessem sustentação a tal projeto mas também de uma ação combinada no interior do movimento sindical. Todavia, além das condições adversas que a crise de emprego suscitava, da necessidade de mobilizar outros setores da sociedade, do aumento e diversificação da população marginalizada e da impermeabilidade do poder público às proposições do sindicalismo mais combativo, o movimento sindical encontrava-se cindido entre duas correntes que, conquanto tenham sido capazes de empreender ações conjuntas em torno de demandas tópicas ${ }^{31}$, passaram boa parte da década buscando marcar suas diferenças. Tais diferenças se expressam tanto na forma de atuação da CUT e da Força Sindical, em sua relação com o Estado e o empresariado, quanto na postura diante das mudanças que se verificam no mundo do trabalho.

Essa divisão nos meios sindicais se reflete no conjunto dos movimentos sociais. Em que pesem as manifestações genéricas e unificadas contra a exclusão e o desemprego, pelo menos em um aspecto a divergência era clara, dificultando a constituição de alianças mais consistentes entre o movimento sindical mais combativo, representado pela CUT, e os demais atores. O discurso desregulamentador que se fortalece nos anos 1990 tem respaldo na sociedade na medida em que a desmercantilização da força de trabalho vista do ângulo da preservação dos direitos atribuídos ao trabalhador formal interessava, segundo aquele discurso, apenas a um grupo cada vez mais reduzido de pessoas, ao passo que o crescente e heterogêneo contingente situado à margem do mercado formal de trabalho desenvolvia expectativas que se distanciavam progressivamente da perspectiva dos trabalhadores formais, tendência que será reforçada pelo discurso governamental que atribuía aos direitos o caráter de privilégios.

Em outros termos, em contraste com os anos 1980, na década de 1990 a defesa dos interesses dos de dentro já não se revela plenamente compatível com a perspectiva dos de fora. O protesto contra a política econômica, contra o desemprego e contra a exclusão unifica os diversos movimentos, mas a formulação de projetos alternativos que contivessem 
o processo de remercantilização foi de certo modo obstada por essa dicotomia.

Em síntese, se no cenário nacional os problemas a serem enfrentados pelo movimento sindical se tornam complexos, na cena sindical a divisão e a disputa entre duas tendências bem delineadas impedem uma ação concertada no combate ao desemprego, à crescente exclusão dele resultante e à reconversão do trabalho em mercadoria. São observadas, pois, formulações direcionadas ao enfrentamento tópico de determinadas questões, seja reagindo às iniciativas estatais, seja ratificando-as, em geral por meio de uma ação que, porquanto desconexa, se revelou incapaz de redefinir as regras do jogo, obtendo-se, no máximo, o adiamento de certos lances. Isso não é pouco se considerarmos aquela conjuntura extremamente adversa de crise do trabalho e de forte ofensiva governamental e empresarial em direção à transformação do trabalho em mercadoria, mas é insuficiente para conter tal tendência.

Assim, na presença de um mercado de trabalho em retração, de um ambiente político pouco permeável à ação reivindicativa dos trabalhadores e de um sindicalismo cindido, a estratégia de confronto predominante nos anos 1980 e a agenda salarial serão substituídas por uma ação mais defensiva, centrada na garantia do nível de emprego. Tendo como preocupação primordial o desemprego, o movimento sindical amplia sua agenda e, de certo modo, sofistica suas formulações, adquirindo uma noção mais integral dos mecanismos que conduzem ao desemprego, agora estrutural e de longa duração. Dessa forma, adota uma agenda orientada por um amplo espectro de demandas, que ora configura uma reação ao processo de remercantilização da força de trabalho, ora expressa uma tentativa de adaptação às novas condições do mercado de trabalho, ora exprime uma rendição à acepção da força de trabalho como mercadoria ${ }^{32}$.

Em outros termos, o movimento sindical foi levado a postular medidas em várias frentes, buscando conter o processo de remercantilização do trabalho impresso nas investidas empresariais e governamentais em direção à flexibilização das relações de trabalho, ao mesmo tempo que assumia funções que correspondiam às expectativas do mercado, procurando atender às novas exigências dos processos de produção reestruturados ${ }^{33}$. 


\section{CONSIDERAÇÕES FINAIS}

No decorrer da República Trabalhista, o movimento sindical brasileiro alcançou conquistas expressivas no sentido da desmercantilização da força de trabalho incluída no universo da cidadania regulada. O elenco de direitos assegurados pela Previdência Social brasileira aos trabalhadores formais era bastante amplo, ao passo que a presença de um mercado de trabalho em expansão e a operação de institutos como a estabilidade no emprego, se não chegavam a eliminar, ao menos esmaeciam o despotismo do capital nos processos de contratação e demissão. Tais dispositivos, contudo, não alcançavam a parcela da população situada à margem do mercado formal de trabalho. Sua inclusão no sistema de direitos existente era apoiada de forma tênue pelo movimento sindical, organizado sob a égide da estrutura corporativa, seja pela ausência de expressões políticas relevantes daquele segmento na cena política, seja pelo temor de que a extensão dos direitos pudesse acarretar a precarização dos benefícios atribuídos aos trabalhadores formais, em função do modelo de financiamento prevalecente. Assegurada por contribuições incidentes sobre a folha de pagamentos das empresas e sobre os salários, corrigidos desde 1954, a estrutura dos benefícios concedida aos trabalhadores do mercado formal era custeada pelo conjunto dos consumidores, incluindo a população marginal, despida de qualquer tipo de proteção assegurada pelo Estado (Delgado, 2001). Assim, as formulações do movimento sindical apontavam a continuidade do desenvolvimento econômico como o mecanismo por excelência de inclusão daquela população no mercado de trabalho e na cidadania. No fim do período, quando se reduz o ritmo de crescimento da economia nacional, demandas como a reforma agrária ganham relevo. Esta é entendida como um mecanismo de retenção da população rural no campo a fim de não afetar, por meio do aumento da população marginal nas cidades, o poder de barganha dos trabalhadores urbanos e reduzir a pressão sobre a estrutura de benefícios prevalecente. Nesse período, o tema do desemprego não chegou a suscitar formulações que apontassem para a instalação efetiva do seguro-desemprego, antes revelando a perplexidade diante de um fenômeno recente na trajetória do capitalismo brasileiro.

Nos anos 1980, o país parece reunir condições ótimas para o alcance de formas avançadas de desmercantilização da força de trabalho. É expressivo o contingente de trabalhadores no mercado formal de trabalho; o avanço do capitalismo no campo contribui para fomentar a orga- 
nização dos trabalhadores rurais; ganham relevo diferenciadas expressões políticas da população urbana; emerge o sindicalismo dos assalariados de classe média; aparecem as centrais sindicais, especialmente a CUT, que favorecem o desenvolvimento de uma percepção ampla dos dilemas do mundo do trabalho. Irrompem no proscênio identidades políticas que interpelam os trabalhadores como classe, ao passo que o ambiente de transição política sugere que o Brasil se encontra em um momento de refundação, o que estimula a disposição de inscrever na ordem institucional dispositivos que corrijam a trajetória de desigualdade que marcou o desenvolvimento capitalista no país. A Carta de 1988 é o desaguadouro da imensa corrente de participação política que marcou a década de 1980. Elaborada por um Congresso majoritariamente conservador - que chegou a mitigar diversos dispositivos sociais aprovados -, a Constituição incorporou um elenco considerável de medidas que apontavam para a desmercantilização da força de trabalho no país e para a superação da segmentação entre os de dentro e os de fora ao dissociar o acesso aos direitos sociais da participação no mercado formal de trabalho. Dos meios sindicais, emanavam reivindicações que expressavam a compatibilidade entre os interesses daqueles dois segmentos, como a defesa da universalização da política social, que viria a alargar o escopo da cidadania no país; a reforma da estrutura fundiária; a luta pela redução da jornada de trabalho, que ampliaria a capacidade de absorção do mercado de força de trabalho; a regulamentação e o incremento do programa de seguro-desemprego, que protegeria o trabalhador expelido do mercado em suas variações cíclicas.

O passado, entretanto, "pesa como um pesadelo no cérebro dos vivos". O peso das escolhas anteriores criou dificuldades, por assim dizer, para a implementação plena dos dispositivos da Constituição de 1988, que não encontrou, ademais, nos diversos governos que se instalaram sob sua égide, a sintonia e a disposição necessárias para torná-la efetiva. Assim, se tomarmos a política de saúde como exemplo, não obstante os avanços reais representados por sua universalização enquanto prerrogativa, acabou por se materializar uma estrutura dual em que o sistema público atende fundamentalmente - e de forma precária - os pobres, ao passo que os estratos médios e superiores da pirâmide social buscam serviços privados que se haviam ampliado com iniciativas tomadas ainda sob o regime militar. Por seu turno, importantes conquistas, como a redução da jornada de trabalho, tiveram seus efeitos sobre o mercado de trabalho mitigados em face da opção empresarial 
pelo recurso ao trabalho extraordinário, cuja supressão foi abordada de maneira extremamente tímida pelo movimento sindical. A premência na busca individual por uma renda adicional que compensasse a escalada inflacionária, em um quadro de intensa rotatividade da força de trabalho - ainda, parcialmente, um legado do período militar -, realçava no movimento sindical a luta pela recomposição dos salários e adiava o tratamento de temas como aqueles a que acabamos de aludir. A própria CUT, principal central sindical na época, viu-se diante da dificuldade de combinar a proposição de redução da jornada de trabalho com a eliminação da hora extra. De todo modo, os anos 1980 correspondem ao momento em que as formulações do movimento sindical mais se aproximam da superação da dicotomia entre os interesses dos de dentro e dos de fora.

Na década de 1990, sopram fortes os ventos gerados pelo moinho satânico do mercado. A crise de refundação dos anos 1980 desembocou em uma solução bonapartista que levou Fernando Collor de Mello ao poder. Inaugurou-se no país um período de desregulamentação e de abertura da economia, acelerando os procedimentos de reestruturação das empresas, afetando a estrutura do mercado de trabalho e contribuindo para a redução do poder de barganha do movimento sindical, que, cindido, opera em um ambiente adverso, marcado pela hegemonia neoliberal. O incremento do desemprego e da informalidade elevou os custos da participação na ação coletiva, afetando a disposição para agir dos trabalhadores, bem como reacendeu a segmentação entre os de dentro e os de fora no mercado de trabalho. A consolidação das centrais sindicais será contrabalançada pela pulverização na base da estrutura sindical, efeito perverso da autonomia conquistada em 1988. Além disso, os diferentes governos revelaram-se pouco propensos a acolher as demandas sindicais. Assim, o movimento sindical foi levado a adotar uma postura de certa forma defensiva. Por um lado, a contínua presença, na pauta sindical, de propostas orientadas para a redução da jornada de trabalho revela a perda de confiança em um papel exclusivo do crescimento econômico para a geração de empregos e a permanência da disposição de lutar pela inclusão social por meio de uma medida que aprofunda a desmercantilização. Por outro, o giro que se verifica no período em direção à qualificação profissional revela como a realidade avassaladora da década neoliberal cobra seu preço, orientando o movimento sindical para as tarefas de preparação dos indivíduos, e não mais por intermédio da ação coletiva, para a renhida dis- 
puta das escassas vagas criadas pelo desenvolvimento capitalista na era do desemprego estrutural.

Se, como afirmamos no início, a desmercantilização da força de trabalho constitui um passo importante na conquista da cidadania e, por conseguinte, na consolidação da democracia - uma vez que reduz o desequilíbrio na correlação de forças entre capital e trabalho, fortalecendo as organizações do trabalho e facilitando a adesão à ação coletiva direcionada a novas conquistas sociais, em um círculo virtuoso que, ao cabo, tende a produzir resultados de soma positiva -, a década de 1990 pode ter significado uma inflexão na trajetória de consolidação da democracia no Brasil. A remercantilização da força de trabalho aprofundou o desequilíbrio de forças entre capital e trabalho, onerando a participação na ação coletiva, que outrora se revelou fundamental para a conquista de diversos direitos ancorados na ideia de cidadania.

As expectativas de romper com esse círculo vicioso que a eleição de Luiz Inácio Lula da Silva suscitou em variados setores da sociedade brasileira, particularmente entre os trabalhadores, até o momento não obtiveram do governo uma resposta que indicasse que um novo cenário estaria por se descortinar. Em que pese a adoção de importantes medidas no campo social, os indicadores ainda permanecem distantes da perspectiva de uma sociedade mais igualitária. A crise política que marcou parte do primeiro mandato do presidente petista adiou o tratamento de questões substantivas que, ao lado da retomada do crescimento econômico verificado nos últimos anos, poderiam fazer a sociedade avançar mais rapidamente em direção à inclusão. A discussão em torno de uma tímida reforma sindical não veio acompanhada de medidas como, por exemplo, a redução da jornada e a supressão do trabalho extraordinário, capazes de promover, efetivamente, uma significativa ampliação do mercado de trabalho que o crescimento da economia per se já não é capaz de assegurar. A forte capacidade demonstrada pelo governo Lula no sentido de superar crises políticas, a retomada do crescimento da economia nacional e os elevados índices de aprovação do governo e do presidente revelam condições razoáveis para a adoção de iniciativas que, a exemplo da redução da jornada de trabalho e da eliminação do trabalho extraordinário, poderiam reinaugurar o círculo virtuoso que nos anos 1980 conteve os ventos da remercantilização que já sopravam em outras partes do mundo.

(Recebido para publicação em agosto de 2008)

(Versão definitiva em março de 2009) 


\section{NOTAS}

1. Para uma tipologia das políticas sociais, conferir Santos (1979:58 e ss).

2. A relação entre bem-estar social, democracia e estabilidade política foi estabelecida por diversos autores, a exemplo de Przeworski (1989). Aceitar tal acepção não implica, naturalmente, ignorar a validade de proposições que vinculam estabilidade política também a contextos autoritários, tal como em Huntington (1975). Trata-se aqui apenas de compreender que a estabilidade de regimes democráticos em geral supõe, para além dos direitos políticos, direitos sociais, tais como concebidos por Marshall (1967).

3. É provável que jamais a força de trabalho tenha assumido integralmente a condição de mercadoria, uma vez que, mesmo no apogeu do liberalismo, se verificam traços de relações de proteção pré-capitalistas, ao mesmo tempo que formas modernas de proteção começavam a se desenvolver (Esping-Andersen, 1990:37).

4. A política bismarckiana é paradigmática desse modelo.

5. Melo lembra que, fundado no princípio da seguridade social, da proteção ao trabalho e da redistribuição, o Welfare State aparece como corolário do processo de desmercantilização. Segundo o autor, "a emergência do WS é indissociável da constituição histórica de atores coletivos, como burocracias públicas, e trabalhadores mobilizados em formas organizacionais específicas, como sindicatos e partidos - e sua subseqüente incorporação à vida política. Estes atores realizaram escolhas estratégicas que tiveram fortes implicações sobre a formação dos WS" (1991:265).

6. Na clássica formulação de Marx, a população excedente constitui um exército industrial de reserva que "pertence ao capital de maneira tão absoluta como se fosse criado e mantido por ele" (1975:733). Essa percepção tem respaldo na literatura sobre exclusão no Brasil dos anos 1950, a exemplo de Kowarick (1981), mas sustentamos que o volume da população excedente naquele período é superior às reservas de força de trabalho necessárias à reprodução do capital mesmo nas condições particulares do desenvolvimento brasileiro, para as quais chama a atenção Oliveira (1981).

7. Em texto clássico, Oliveira (1981) indaga acerca da relação de causalidade estabelecida entre a incapacidade de retenção da mão-de-obra pelo setor primário e de absorção desta pelo setor secundário e o inchaço do terciário. O autor sugere que o crescimento do terciário no Brasil, expresso na crescente absorção de força de trabalho, tanto em termos relativos quanto em termos absolutos, é inerente à forma como se processou a acumulação capitalista no país. Desse modo, o incremento do setor terciário "faz parte do modo de acumulação urbano adequado à expansão do sistema capitalista no Brasil; não se está em presença de nenhuma 'inchação', nem de nenhum segmento 'marginal' da economia" (ibidem:31). Assim, o crescimento do setor de serviços não é contraditório com a forma de acumulação nem com a expansão global da economia, já que "os serviços realizados à base de pura força de trabalho, que é remunerada a níveis baixíssimos, transferem permanentemente, para as atividades econômicas de corte capitalista, uma fração de seu valor, 'mais-valia' em síntese" (ibidem:33). Por seu turno, Kowarick (1981) indica que a transição rural-urbana se realiza constituindo amplos contingentes ocupados em pequenos serviços, já que o crescimento de postos de trabalho gerados direta ou indiretamente na indústria não é suficiente para absorver tais segmentos da população. Esses contingentes apresen- 
tam volume superior ao necessário para que o exército industrial de reserva cumpra seu papel de reprodução do capital, criando-se um segmento populacional permanentemente marginalizado. De um modo ou de outro, o que cumpre ressaltar é que, a despeito do lugar que ocupam ou do papel que desempenham no desenvolvimento capitalista nas condições brasileiras, tais segmentos, ocupados em pequenos serviços, situam-se à margem da cidadania, uma vez que, associados a um setor tipicamente informal, não têm acesso à política social, atribuída no Brasil apenas aos trabalhadores formais.

8. O primeiro momento constitutivo do mercado de trabalho brasileiro corresponderia à fase de expansão acelerada do complexo cafeeiro, quando se desenvolvem relações diferenciadas nas relações de trabalho agrícolas (colonato, parceria, assalariamento etc.) e nas relações de trabalho assalariadas (avulsas ou não) nas atividades urbanas. O segundo se desenvolve a partir da crise de 1929, quando o trabalho vinculado a atividades urbanas ganha expressão cada vez maior, apesar da preservação do elevado peso do trabalho agrícola (Baltar e Dedecca, 1992:4-5).

9. O número de contribuintes do sistema previdenciário foi publicado regularmente entre 1948 e 1966 (implementação do Instituto Nacional de Previdência Social INPS). Diante da dificuldade de se mensurar o mercado formal de trabalho no Brasil dos anos 1950, optamos por contrastar os números de contribuintes da Previdência com os números da PEA a fim de obtermos uma aproximação com a proporção real de empregados no setor formal em relação à PEA urbana (cf. Lobo, 2005).

10. As associações de trabalhadores não inseridos no mercado formal é recente no país, com exceção dos rurais. Contribui para isso, além da propalada dificuldade de organização de autônomos, domésticos, eventuais - em função da própria natureza dessas ocupações -, a presença de uma estrutura sindical oficial que só permitia a criação de sindicatos por categorias reconhecidas pelo Ministério do Trabalho.

11. Cf. números e natureza das greves em Sandoval (1994).

12. Os movimentos sociais existentes nos centros urbanos, naquele período, em geral se destinavam à defesa de interesses bastante específicos, a exemplo dos Comitês Pró-Melhoramento, que representavam moradores de bairros de periferia, e das Uniões de Defesa Coletiva, agrupando habitantes de vilas e favelas. Esses movimentos se proclamavam apolíticos e portavam reivindicações relacionadas às condições de moradia, como saneamento e transporte (Moisés et alii, 1978; Somarriba et alii, 1984). De sua parte, os trabalhadores rurais começam a sair da passividade política a partir de meados dos anos 1950, mas é só a partir do fim da década que suas organizações adquirem peso na cena nacional, a exemplo das Ligas Camponesas. O mesmo se verifica em relação aos estudantes, que começam a se constituir como ator coletivo nos anos 1950, mas só ganham visibilidade no cenário político na passagem para os anos 1960, quando, paralelamente à defesa de interesses específicos, assumem bandeiras "macro", como a Reforma Agrária.

13. O estudo da participação empresarial, dessa perspectiva analítica, na gênese e na trajetória da política social brasileira, particularmente a Previdência Social, de 1930 a 1998, foi feito por Delgado (2001).

14. Para os comunistas, por exemplo, a unicidade era válida para evitar a fragmentação. O imposto sindical, embora dividisse opiniões, era considerado instrumento útil para subsidiar a ação mobilizadora dos sindicatos (cf., por exemplo, Santana, 2001). 
15. A estrutura sindical corporativa parece ter sido a fórmula encontrada pelo governo Vargas para facilitar o processo de acumulação nos anos 1930. O processo de industrialização desencadeado a partir dali, seja enquanto "industrialização restringida", seja na industrialização pesada dos anos 1950, não opõe os setores agrários aos industriais (Mello, 1984; Oliveira, 1981). Para os primeiros, assegurava-se a preservação das formas de dominação já existentes no campo brasileiro, como uma espécie de compensação à reorientação das ações do Estado no sentido da industrialização, clara a partir de 1937. Já o movimento operário, submetido à estrutura corporativa, deixava de existir como ator autônomo. O caráter retardatário da formação do capitalismo no Brasil, ao lado de exigir uma forte presença do Estado e a transferência de recursos gerados no polo exportador - via confisco cambial -, implicou também a contenção dos salários dos trabalhadores industriais. Para garanti-la, tornava-se necessária, na perspectiva do getulismo, a interdição da ação operária autônoma. Tal papel caberia à estrutura sindical, tal como foi montada no Brasil. Com sua imposição, buscava-se criar um hiato entre as duas gerações do movimento operário, que no Estado Novo é submetido à passividade e/ou à participação tutelada. Subjacente a essa política havia a intenção de suprimir os conflitos entre as classes e substituí-los por uma estrutura que possibilitasse a cooperação entre os diversos setores sociais a fim de facilitar a implementação da política de industrialização nacional em bases legítimas, isto é, assentada em certo consenso entre camadas sociais envolvidas no processo. Nessa medida, o modelo corporativo de intermediação de interesses apresenta-se como uma terceira via, situada a meio caminho entre as formas autoritárias e a democracia pluralista (Lobo, 1995).

16. A participação nas greves foi aferida por Sandoval (1994). Para um período mais recuado, Simão (1966) oferece dados referentes ao Estado de São Paulo.

17. A elevada rotatividade empregatícia não é uma novidade dos anos 1980. A introdução do Fundo de Garantia do Tempo de Serviço (FGTS), ao suprimir certos encargos associados aos processos de dispensa previstos na vigência do instituto da estabilidade, favoreceu a rotatividade de mão-de-obra, em um contexto em que já era significativa a oferta de força de trabalho para uso do capital (Werneck Vianna, 1999:336 e ss). Nos anos 1980, a acentuação desse processo pode ser creditada às flutuações da economia nacional no período e à adoção de estratégias de ação empresariais nesse ambiente de instabilidade macroeconômica.

18. "Participação" e "redistribuição", tais como concebidos, respectivamente, por Dahl (1988) e Santos (1993).

19. A disposição de aproximar-se de outros movimentos populares está explicitada em diversos documentos da Central Única dos Trabalhadores (CUT) (Lobo, 2005), em formulações que partem da compreensão de que "a exploração do trabalhador não se dá só no local de trabalho, mas também no seu dia-a-dia" (CUT, 1988:48). No Caderno de Resoluções do terceiro congresso nacional da Central, assinala-se que "a população vem resistindo e se organizando [...], os movimentos populares (mutuários, sem-terra, lutas de transporte, moradia, saúde, educação, favelas, cortiços, etc.) e entidades compõem hoje uma força de pressão sobre [a] aliança entre o Estado e o capital [...], os vários movimentos, sindicatos e entidades da sociedade civil vêm buscando a unificação de suas bandeiras de ação" (ibidem:53). No congresso anterior, a CUT ressaltava a importância de "apoiar, incentivar e contribuir para a organização das 
lutas populares por transporte, moradia, saúde, educação e abastecimento e outras, desenvolvendo a sua unidade com o movimento sindical" (CUT, 1986:21).

20. Ainda segundo Boschi (1987:138), “a intensificação das práticas associativas de natureza politizada certamente não estava incluída nos planos governamentais. Quando muito o projeto de abertura tinha por objetivo uma sociedade domesticada, com grupos de interesse atuando dentro de estreitos limites [...]. Ainda que a politização de segmentos organizados da sociedade não tenha ameaçado o projeto de transição gradual para a democracia, ele certamente afetou o seu ritmo".

21. Obviamente que não se pretende defender aqui, contrariamente a todas as evidências, que o processo tenha sido linear, ao modo marshalliano. Obedeceu a uma trajetória pendular, ou mesmo espiralar, que do ponto de vista das elites era fundamental para a preservação de suas posições de mando; e para os "de baixo" representava certa garantia de que não haveria retrocessos políticos ou qualquer espécie de contrarreforma. A despeito de o processo de afirmação da democracia formal não ter sido linear, do descompasso entre os eixos de institucionalização e de participação, da instabilidade permanente que tal descompasso ocasiona e da persistência de procedimentos autoritários no processo de democratização, não parecia haver espaço para um eventual retorno ao ordenamento autoritário que marcara o regime militar. É precisamente nesse sentido que estamos afirmando que, na política, a sociedade brasileira avançava firmemente em direção à democracia. Uma boa análise acerca do compasso democratização/política social e do caráter não linear desse processo encontra-se em Melo (1990:447 e ss).

22. A Reforma Partidária (Lei no $6.767 / 79$ ) fez-se à luz da expectativa de cindir a oposição e, segundo Meneguello (1989), de "garantir a representação das classes trabalhadoras sob uma sigla confiável - o renascido Partido Trabalhista Brasileiro". O surgimento do PT, com base na proposta de tornar-se uma agremiação com forte enraizamento nas bases sociais e uma atuação voltada para o reforço dos laços com as lutas populares, representou, pois, uma novidade do ponto de vista organizacional e também um imprevisto em meio à liberalização conduzida de cima.

23. Em que pese a forte presença de sindicalistas na formação do PT, este recebeu, ao longo de seu processo de organização, a adesão de lideranças de variados movimentos sociais, tais como grupos de negros, feministas, amigos de bairro, movimentos libertários etc., além de membros da ala progressista da Igreja (Meneguello, 1989:64).

24. Importante lembrar que a CUT, em que pese sua afirmação como ator relevante na cena política e sua hegemonia no ambiente sindical, não dispunha da prerrogativa de participar das negociações coletivas, competência dos sindicatos de base (Cardoso, 2003). Tal impedimento pode ter determinado a ampliação do escopo de sua pauta e ação para além dos interesses dos trabalhadores sindicalizados ou inseridos no mercado formal de trabalho.

25. A atuação das bancadas partidárias na Constituinte é elucidativa da postura dos partidos em face das matérias de interesse dos trabalhadores. Nesse ponto, além do PT, cumpre indicar o Partido Democrático Trabalhista (PDT), o Partido Socialista Brasileiro (PSB), o Partido Comunista do Brasil (PC do B) e o Partido Comunista Brasileiro (PCB) como partidos que votaram sistematicamente a favor dos interesses dos trabalhadores. Outros, como o Partido do Movimento Democrático Brasileiro (PMDB), também abrigavam parlamentares portadores de projetos favoráveis aos trabalhadores e que votavam sistematicamente a favor das referidas matérias, mas constitu- 
íam exceções. No caso do PMDB, muitos parlamentares compunham o centrão, articulação conservadora formada pelo Partido Democrático Social (PDS), Partido da Frente Liberal (PFL), Partido Liberal (PL), Partido Trabalhista Brasileiro (PTB) e vários parlamentares do PMDB (cf. DIAP, 1988).

26. No caso dos avulsos, por exemplo, os partidos de esquerda defendiam que dispusessem de igualdade de direitos em relação aos trabalhadores com vínculo empregatício, enquanto o centrão pretendia limitar a isonomia apenas aos direitos concernentes à área previdenciária. Quanto aos domésticos, as correntes progressistas defendiam que a Constituição assegurasse explicitamente uma série de direitos, ao passo que o centrão remetia, de forma vaga, a situação dos empregados domésticos à legislação ordinária. Quanto aos trabalhadores rurais, o centrão negava-lhes uma série de direitos defendidos pelos progressistas diante do entendimento de que a fixação de direitos deveria condicionar-se às peculiaridades de sua atividade (cf. Lobo, 2005:161).

27. Naquele período, a crise financeira do Estado, derivada do forte endividamento interno e externo, inviabilizava que se processassem novas fugas para frente, impondo reajustes estruturais na economia nacional (Soares, 1999:153).

28. Segundo Cardoso (2003:41), "os sistemas de qualidade são canais institucionais por meio dos quais problemas de produção podem ser diretamente negociados entre trabalhadores e gerência, sem a interferência sindical. Queixas não devem exceder os portões da fábrica [...], o 'novo local de trabalho' caracteriza-se por parcerias e cooperação entre os agentes".

29. Projeto que começa a ser construído a partir das resoluções políticas do IV e do V Congresso da CUT.

30. Cumpre mencionar que, a despeito da fragilização do movimento sindical e da adesão de parte do sindicalismo ao projeto de contrarreforma que o Estado e o capital buscam empreender nos anos 1990, que tem como fundamento a tensão que se reacendeu entre política social e necessidades do mercado, não se obteve um consenso passivo das classes em torno desse projeto. Nos termos de Mota (1995:64), "apesar das crises gerarem impactos negativos sobre os empregos, salários e mecanismos de seguridade social, elas não criam, mecanicamente, as condições para a burguesia operar sitiamentos nas práticas sociais e nos comportamentos dos trabalhadores". Assim, o movimento sindical, particularmente o sindicalismo cutista, preserva, ainda que em um contexto demasiadamente adverso, algumas chances de capitalizar os descontentamentos e canalizá-los para o apoio ativo em torno de um projeto alternativo que tenha em vista a integração à cidadania sem que esta tenha de se associar à subtração de direitos, mas, ao contrário, à sua universalização.

31. A exemplo da luta pela redução da jornada de trabalho e do aperfeiçoamento do programa de seguro-desemprego.

32. Em Lobo (2005), verificamos que, enquanto a CUT alterna entre a primeira e a terceira perspectiva, a Força Sindical pratica um sindicalismo que pode ser enquadrado na segunda e na terceira. $\mathrm{O}$ tratamento direcionado à qualificação profissional é elucidativo. Para a Força Sindical, o envolvimento em políticas de formação aparece como estratégia desde o início, como meio de adequar a ação sindical à conjuntura dos anos 1990. Já no âmbito da CUT, o tema sempre foi fonte de controvérsias entre as tendências que atuam no interior da Central, encontrando resistência nas correntes de 
esquerda orientadas pela noção de que a qualificação profissional é uma exigência do mercado, e não uma função do sindicato, e que, ademais, qualificar mão-de-obra não gera vagas no mercado de força de trabalho. No entanto, no fim da década, a entidade parece ter despendido esforços cada vez maiores em direção à qualificação profissional e à intermediação de mão-de-obra. Para além das possibilidades de esses procedimentos estarem orientados pelos interesses dos trabalhadores - empregados e desempregados -, o que parecia estar em jogo era a própria sobrevivência da entidade, uma vez que, nesse contexto adverso para a ação coletiva, a adesão a programas de treinamento e a intermediação de mão-de-obra talvez configurassem uma estratégia dos sindicatos e das centrais de aproximação com os trabalhadores, tornando-se, assim, fonte de legitimação, bem como de captação de recursos. Por outro lado, a ação voltada para a formação profissional exprime certa rendição aos imperativos do mercado e ao discurso da empregabilidade, em uma admissão tácita à própria mercantilização da força de trabalho, colidindo, dessa maneira, com a perspectiva que se tornou hegemônica nos anos 1980.

33. Convém adiantar que a qualificação por meio dos sindicatos dispensa os empresários de investir no treinamento de trabalhadores que serão contratados por um curto espaço de tempo. Além disso, o tipo de formação que as empresas exigem para seus funcionários "permanentes" é de outra natureza, que não está ao alcance dos sindicatos, de modo que o problema não é o investimento em programas de qualificação, fundamental nesse período de mudança de paradigma produtivo. O que está em questão é a substituição de uma postura reivindicativa mais ampla por uma ação limitada, voltada para a qualificação profissional, por um lado, e a compreensão de que o mercado exige, para compor seu quadro mais estável, trabalhadores com formação regular sólida. A qualificação oferecida pelos sindicatos e centrais não forma trabalhadores caros ao mercado, apenas amplia a oferta de trabalhadores a serem selecionados, absorvidos e expelidos pelo mercado de acordo com seus critérios, necessidades e prerrogativas mais imediatas. Por outro lado, a oferta de programas de qualificação parece atender simultaneamente às expectativas dos trabalhadores em busca de qualificação, servindo também de alento ao desempregado, trazendo novos elementos para a discussão. 


\section{REFERÊNCIAS BIBLIOGRÁFICAS}

BALTAR, Paulo Eduardo de Andrade e DEDECCA, Claudio Salvadori. (1992), "Notas sobre o Mercado de Trabalho no Brasil durante a Industrialização Restringida". Cadernos do Cesit, no 12, Unicamp.

e HENRIQUE, Wilnês. (1996), "Mercado de Trabalho e Exclusão Social no Brasil", in C. A. B. de Oliveira e J. E. L. Mattoso (orgs.), Crise e Trabalho no Brasil. São Paulo, Scritta.

BOSCHI, Renato. (1987), A Arte da Associação. São Paulo/Rio de Janeiro, Vértice/IUPERJ.

BRUNHOFF, Suzanne. (1991), A Hora do Mercado: Crítica do Liberalismo. São Paulo, Editora Unesp.

CARDOSO, Adalberto. (2003), A Década Neoliberal e a Crise dos Sindicatos no Brasil. São Paulo, Boitempo.

CUT - Central Única dos Trabalhadores. (1986), Caderno de Resoluções, 2o Congresso Nacional da CUT, 31 de julho-3 de agosto, Rio de Janeiro.

(1988), Boletim Nacional (ed. especial), 3- Congresso Nacional da CUT, 7-11 de setembro, Vitória.

. (2000), Texto Base da Direção Nacional, 7o Congresso Nacional da CUT, 16-19 de agosto, São Paulo.

DAHL, Robert. (1988), Análise Política Moderna. Brasília, Ed. UnB.

DE SWAAN, Abram. (1988), In Care of the States. Oxford, Oxford University Press.

DELGADO, Ignacio Godinho. (2001), Previdência Social e Mercado no Brasil. São Paulo, LTR.

DIAP - Departamento Intersindical de Assessoria Parlamentar. (1988), Relatório, 1886/1987. Brasília, DIAP.

ESPING-ANDERSEN, Gøsta. (1990), The Three Worlds of Welfare Capitalism. Princeton, Princeton University Press.

FARIA, Vilmar. (1986), “Mudanças na Composição do Emprego e na Estrutura de Ocupações", in E. Bacha e H. S. Klein (orgs.), A Transição Incompleta: Brasil desde 1945. Rio de Janeiro, Paz e Terra, vol. 1.

FIORI, José Luís e TAVARES, Maria da Conceição. (1993), Desajuste Global e Modernização Conservadora. Rio de Janeiro, Paz e Terra.

HUNTINGTON, Samuel. (1975), A Ordem Política nas Sociedades em Mudança. Rio de Janeiro/São Paulo, Forense Universitária/Edusp.

KOWARICK, Lucio. (1981), Capitalismo e Marginalidade na América Latina. Rio de Janeiro, Paz e Terra.

LAVAREDA, Antonio. (1991), A Democracia nas Urnas. Rio de Janeiro, Rio Fundo/IUPERJ.

LINHARES, Maria Yedda e SILVA, Francisco Carlos Teixeira. (1999), Terra Prometida: Uma História da Questão Agrária no Brasil. Rio de Janeiro, Campus. 
LOBO, Valéria Marques. (1995), Democracia e Corporativismo no Brasil. Dissertação de mestrado, UFMG, Belo Horizonte.

. (2005), Os Elos e os Nós. Tese de doutorado, IUPERJ, Rio de Janeiro.

MARSHALL, Thomas Humprey. (1967), Cidadania, Classe Social e Status. Rio de Janeiro, Zahar.

MARX, Karl. (1975), O Capital. Rio de Janeiro, Civilização Brasileira.

MATTOSO, Jorge. (1995), A Desordem do Trabalho. São Paulo, Scritta.

. (1999), "Produção e Emprego: Renascer das Cinzas", in I. Lesbaupin (org.), O Desmonte da Nação: Balanço do Governo FHC. Petrópolis, Vozes.

MELO, Marcus André. (1990), “A Formação de Políticas Públicas e a Transição Democrática: O Caso da Política Social”. DADOS, vol. 33, no 3, pp. 443-470.

. (1991), "Interesses, Atores e a Construção da Agenda Social do Estado no Brasil, 1930-90", in Associação Nacional de Pós-Graduação e Pesquisa em Ciências Sociais (org.), Anuário Ciências Sociais Hoje. São Paulo, Vértice.

MELLO, João Manuel Cardoso de. (1984), O Capitalismo Tardio: Contribuição à Revisão Crítica da Formação e do Desenvolvimento da Economia Brasileira (3a ed.). São Paulo, Brasiliense.

MENEGUELLO, Rachel. (1989), PT: A Formação de um Partido. Rio de Janeiro, Paz e Terra.

MOISÉS, José Álvaro et alii. (1978), Contradições Urbanas e Movimentos Sociais (2a ed.). Rio de Janeiro, Paz e Terra/Cedec.

MOTA, Ana Elizabete. (1995), Cultura da Crise e Seguridade Social. São Paulo, Cortez.

NOGUEIRA, Arnaldo Mazzei. (2000), Perspectivas do Trabalho e do Sindicalismo no Brasil. Trabalho apresentado no XXIV Encontro Anual da ANPOCS, Petrópolis, 23-27 de outubro.

OLIVEIRA, Francisco. (1981), A Economia Brasileira: Crítica à Razão Dualista. Petrópolis, Vozes.

POLANYI, Karl. (1980), A Grande Transformação: As Origens da Nossa Época. Rio de Janeiro, Campus.

PRZEWORSKI, Adam. (1989), Capitalismo e Social-Democracia. São Paulo, Companhia das Letras.

RODRIGUES, Alberto Tosi. (2001), “Ciclos de Mobilização Política e Mudança Institucional no Brasil". Revista de Sociologia e Política, vol. 17, pp. 33-44.

SANDOVAL, Salvador. (1994), Os Trabalhadores Param: Greves e Mudança Social no Brasil (1945-1990). São Paulo, Ática.

SANTANA, Marco Aurélio. (2001), Homens Partidos: Comunistas e Sindicatos no Brasil. São Paulo, Boitempo.

SANTOS, Wanderley Guilherme dos. (1979), Cidadania e Justiça. Rio de Janeiro, Campus. . (1993), Razões da Desordem. Rio de Janeiro, Rocco.

SIMÃO, Azis. (1966), Sindicato e Estado. São Paulo, Dominus. 
SOARES, Laura Tavares R. (1999), Ajuste Neoliberal e Desajuste Social na América Latina. Rio de Janeiro, UFRJ.

SOMARRIBA, Maria das Mercês Gomes et alii. (1984), Lutas Urbanas. Petrópolis, Vozes.

SPOSATI, Aldaíza. (1995), "A Assistência Social e a Trivialização dos Padrões de Reprodução Social", in A. Sposati, M. do C. B. Falcão e S. M. F. Teixeira (orgs.), Os Direitos dos (Des)Assistidos Sociais. São Paulo, Cortez, pp. 5-30.

WERNECK VIANNA, Luiz. (1999), Liberalismo e Sindicato no Brasil (2a ed.). Belo Horizonte, Ed. UFMG. 


\section{ABSTRACT \\ Decommodification of Labor from the Trade Union Movement's \\ Perspective (Brazil, 1950-2000)}

The article adopts a comparative perspective to discuss the trade union movement's position towards the informal labor market in Brazil in the 1950s, 1980s, and 1990s, based on an analysis of union discourse regarding social and employment policy. The author seeks to grasp to what extent such discourse objectifies the decommodification of the workforce. Important variables in the definition of the trade union behavior and choices include job structure, organizational format, and the relationship between the unions and the state and other actors on the Brazilian national scene. The goal is thus to identify the influence of such factors on the definition of the trade union agenda in each period.

Key words: work market; social policy; trade unionism

\section{RÉSUMÉ \\ Démercantilisation du Travail dans la Perspective du Mouvement Syndical (Brésil-1950-2000)}

Dans cet article, on discute, à partir d'une perspective comparative, l'attitude du mouvement syndical par rapport au marché du travail informel au Brésil, dans les années 1950, 1980 et 1990, en s'appuyant sur une analyse du discours syndical concernant la politique sociale et l'emploi. On cherche à comprendre dans quelle mesure ce discours prône la démercantilisation de la force du travail. Comme variables importantes de la définition du comportement et des choix du mouvement syndical, on considère la structure professionnelle, le mode d'organisation, ainsi que les relations des syndicats avec l'État et les autres acteurs présents sur la scène nationale. Il s'agit donc d'observer l'influence de ces facteurs sur la définition des priorités syndicales à chaque période.

Mots-clé: marché du travail; politique sociale; syndicalisme 